Article

\title{
Susceptibility of Various Developmental Stages of the Fall Armyworm, Spodoptera frugiperda, to Entomopathogenic Nematodes
}

\author{
Rajendra Acharya ${ }^{1,2} \oplus$, Hwal-Su Hwang ${ }^{1,3}$, Md Munir Mostafiz ${ }^{1,2} \oplus$, Yeon-Su Yu ${ }^{4}$ \\ and Kyeong-Yeoll Lee ${ }^{1,2,3,5, * \mathbb{D}}$ \\ 1 Department of Applied Biosciences, College of Agriculture and Life Sciences, \\ Kyungpook National University, Daegu 41566, Korea; racharya2048@gmail.com (R.A.); \\ bgtwo2@naver.com (H.-S.H.); munirmostafiz12@gmail.com (M.M.M.) \\ Institute of Plant Medicine, Kyungpook National University, Daegu 41566, Korea \\ Quantum Bio Research Center, Kyungpook National University, Gunwi 39061, Korea \\ Daedong Tech, Gyeongsan 38401, Korea; ysyu1973@naver.com \\ Institute of Agricultural Science and Technology, Kyungpook National University, Daegu 41566, Korea \\ * Correspondence: leeky@knu.ac.kr; Tel.: +82-53-950-5759 or +82-10-7164-5701
}

Received: 19 November 2020; Accepted: 3 December 2020; Published: 7 December 2020

check for updates

Simple Summary: The fall armyworm, Spodoptera frugiperda, native to Central and South America, has recently invaded Africa and Asia, causing serious economic damage to various crops. The chemical control of fall armyworm is not effective due to the development of pesticide resistance as well as environmental contamination. Alternatively, biological control using natural enemies can be used successfully in a sustainable way. Entomopathogenic nematodes are soil-dwelling natural enemies for many underground pest insects including lepidopteran caterpillars. This study evaluates the virulence of several entomopathogenic nematodes on different developmental stages of fall armyworm. We found that all the larval and pupal stages of fall armyworm were highly susceptible to the entomopathogenic nematodes. Our study provides important information of entomopathogenic nematodes for the practical application of biological control of fall armyworm.

\begin{abstract}
The fall armyworm, Spodoptera frugiperda, which is native to Central and South America, has recently invaded Africa and Asia, causing serious damage to various crops. Although management to date has been largely unsuccessful, entomopathogenic nematodes (EPNs) are a potential biological control agent that could be used to control the late larval and pupal stages of $S$. frugiperda that dwell under the ground. Here, we compared the virulence of seven EPNs against larval and pupal stages of S. frugiperda. In a Petri dish assay, both Heterorhabditis indica and Steinernema carpocapsae were highly virulent against younger larvae, whereas $S$. arenarium and S. longicaudum were highly virulent against older larvae. In contrast, H. bacteriophora, Heterorhabditis sp., and S. kushidai showed low virulence against all larval stages. In soil column and pot assays, H. indica, S. carpocapsae, and S. longicaudum were highly virulent against late larval and pupal stages compared with the other EPN species. Thus, H. indica, S. carpocapsae, and S. longicaudum are recommended for the biological control of S. frugiperda. Our study provides important information of EPNs for the practical application of biological control of fall armyworm.
\end{abstract}

Keywords: biological control; alien invasive species; virulence assays; Heterorhabditis indica; Steinernema carpocapsae; Steinernema longicaudum; sustainable management 


\section{Introduction}

The fall armyworm, Spodoptera frugiperda (J.E. Smith) (Lepidoptera: Noctuidae), native to Central and South America, was introduced into Africa in 2016 and then rapidly spread into Asia, reaching Korea and Japan by 2019 [1-4]. The species is a polyphagous pest that causes significant economic loss in agriculture by damaging crops such as corn, rice, wheat, sorghum, beans, potato, and cotton [5-7]. The current $S$. frugiperda strains in Africa mostly infest corn crops, in which they reduce the yield by up to $57 \%$ [8].

Various pesticides have been applied in an attempt to control S. frugiperda in the environment. However, chemical control has not been efficacious because $S$. frugiperda has developed resistance to commonly used insecticides such as lambda-cyhalothrin, chlorpyrifos, spinosad, and lufenuron [9-11]. Although Bacillus thuringiensis (Bt) is often used as a biological control agent, S. frugiperda has also become resistant to $\mathrm{Bt}$ toxins $[12,13]$. Given the issues with resistance, and the fact that repeated pesticide use can negatively affect human health and environmental safety [14,15], it remains necessary to develop effective $S$. frugiperda control strategies, which could include biological control with natural enemies such as predators, parasitoids, and pathogens $[8,16,17]$. Indeed, biological control agents are highly recommended alternatives to hazardous chemical pesticides for the sustainable management of S. frugiperda [18].

Entomopathogenic nematodes (EPNs) can be used as biological control agents to control insect pests including various lepidopteran species [19-21]. In two EPN families, Heterorhabditidae and Steinernematidae, 116 species have been reported [22], some of which have been mass-reared and commercialized in various countries for the purposes of pest control [23-28]. The mode of action of EPNs, as previously established in many studies [29-35], is to penetrate the host insect through natural openings, such as the mouth, anus, and spiracles, and then release the mutualistic bacteria that they carry (Photorhabdus spp. and Xenorhabdus spp. in Heterorhabditidae and Steinernematidae, respectively); the bacteria reproduce and generate various metabolites and toxins that kill the host insect through septicemia or toxemia. However, the virulence of each EPN varies according to the species of host insect [36-38].

The virulence of EPNs not only depends on the host species but also their developmental stage [28,34,39-42]. For example, the virulence of Steinernema carpocapsae and Heterorhabditis indica was higher in the younger larval stage of Spodoptera litura [28] and the older larval stage of Bradysia impatiens [41]. Previous studies have suggested that EPNs have potential as biological control agents against S. frugiperda $[19,21,43,44]$; however, the virulence of EPNs at the different developmental stages of $S$. frugiperda has not yet been investigated.

In the present study, therefore, we evaluated the virulence of seven EPNs against larvae and pupae of S. frugiperda. Five of these EPNs, namely H. bacteriophora, H. indica, S. arenarium, S. carpocapsae, and S. longicaudum, are known to be highly virulent in many other insect species and are already used for pest control in the field [22,45-48]. In addition, the virulence of two newly collected and identified EPNs, namely Heterorhabditis sp. and S. kushidai, against S. frugiperda was tested for the first time. The virulence of $S$. kushidai to scarab beetle larvae has been reported, but its effects on lepidopteran larvae are not known $[49,50]$. The aim of our study is to provide the important information of EPNs for the practical application of biological control of fall armyworm.

\section{Materials and Methods}

\subsection{Insects and Entomopathogenic Nematodes}

Spodoptera frugiperda larvae were collected in August 2019 from a cornfield in Gyeongsan, Gyeongbuk province, Korea. The colony was maintained at $25 \pm 1{ }^{\circ} \mathrm{C}$ and $60 \pm 5 \%$ relative humidity (RH) under a 14:10 h light/dark cycle. Larvae were fed an artificial diet (Product number F9772; Frontier Scientific Services, Newark, DE, USA) prepared with $3.8 \mathrm{~g}$ of agar, $28.80 \mathrm{~g}$ of dry mix for lepidopteran insects, and $200 \mathrm{~mL}$ of distilled water (DW) [28]. 
Four EPN species, namely H. bacteriophora, S. arenarium, S. carpocapsae, and S. longicaudum, were obtained from Daedong Tech, Daegu, Korea. Both H. indica and Heterorhabditis sp. were isolated from Nepal, whereas S. kushidai was collected from Taejongdae in Busan, Korea. The EPNs were maintained using Galleria mellonella larvae as described by Woodring and Kaya [51]. Freshly harvested nematodes (not more than 2 weeks old) were used in the experiments.

\subsection{Nematode Infection of S. frugiperda Larvae}

\subsubsection{Effect of Larval Developmental Stage and Exposure Time on EPN Virulence}

First- to sixth-instar larvae were used in the experiments. Each stage of larvae was separately placed in a Petri dish ( $n=5$ per $90 \mathrm{~mm}$ Petri dish) lined with $90 \mathrm{~mm}$ diameter qualitative filter paper (Hyundai Micro, Seoul, Korea) and containing $2.5 \mathrm{~g}$ of Spodoptera artificial diet. The virulence of all seven EPN species was determined by adding 250 infective juveniles (IJs) in $1 \mathrm{~mL}$ of DW to the surface of the filter paper in each dish. In the control treatment, $1 \mathrm{~mL}$ of DW only was applied. The Petri dishes were then sealed with Parafilm (Bemis Company Inc., Neenah, WI, USA) and kept at $25 \pm 1{ }^{\circ} \mathrm{C}$ and $60 \pm 5 \% \mathrm{RH}$. Larval mortality was determined at $24 \mathrm{~h}$ intervals for up to $72 \mathrm{~h}$ post-treatment. Each treatment contained ten larvae and the experiment was repeated three times on different dates.

\subsubsection{Efficacy of EPNs against $S$. frugiperda Larvae in a Soil Column Assay}

A soil column assay was performed as described by Acharya et al. [28]. Glass cylinders (12 cm in height $\times 3 \mathrm{~cm}$ in diameter) were filled to the $10 \mathrm{~cm}$ mark with autoclaved nursery media (Punong, Gyeongju, Korea) containing 68\% coco peat, $7 \%$ perlite, $14.729 \%$ peat moss, 3\% vermiculite, $7 \%$ zeolite, $0.243 \%$ fertilizer, $0.024 \% \mathrm{pH}$ regulator, and $0.004 \%$ moisture. A sixth-instar $S$. frugiperda larva was then added to the cylinder and covered with $2 \mathrm{~cm}$ of soil. Subsequently, $5 \mathrm{~mL}$ of DW containing 600 IJs was applied to the soil medium. The control glass cylinder received only DW. Both ends of the cylinders were covered with mesh netting before being placed vertically in an environmental chamber at $25 \pm 1{ }^{\circ} \mathrm{C}$ and $60 \pm 5 \% \mathrm{RH}$. Mortality was recorded at $24 \mathrm{~h}$ intervals for up to $72 \mathrm{~h}$ post-treatment. Each treatment contained three larvae and the experiment was repeated three times on different dates.

\subsubsection{Efficacy of Selected EPNs against S. frugiperda Larvae in a Pot Assay}

Corn seedlings were grown in plastic pots $(9 \mathrm{~cm}$ in diameter and $9 \mathrm{~cm}$ deep) with nursery media (Punong, Gyeongju, Korea). Spodoptera frugiperda sixth-instar larvae $(n=15)$ were placed into three corn pots (30 days old after transplantation) within an acre cage $(40 \times 40 \times 50 \mathrm{~cm})$. Subsequently, $H$. bacteriophora, H. indica, S. arenarium, S. carpocapsae, and S. longicaudum were applied to each pot separately at a density of $25 \mathrm{IJs} / \mathrm{cm}^{2}$. DW alone was applied to the control pot. Larval mortality was recorded for 5 days post-treatment. The experiment was repeated three times on different dates.

\subsection{Nematode Infection of S. frugiperda Pupae}

Five-day-old $S$. frugiperda pupae $(n=5)$ were placed in a $90 \mathrm{~mm}$ Petri dishes filled with $10 \mathrm{~g}$ of nursery media (Punong, Gyeongju, Korea). The effects of all seven EPN species were determined by adding $600 \mathrm{IJs}$ in $5 \mathrm{~mL}$ of DW to each dish. DW alone was added to the control dishes. The Petri dishes were then sealed with Parafilm (Bemis Company Inc.) and kept at $25 \pm 1{ }^{\circ} \mathrm{C}$ and $60 \pm 5 \% \mathrm{RH}$. The adult eclosion rate was recorded for 5 days post-treatment. Each treatment contained ten pupae and the experiment was repeated three times on different dates.

\subsection{Assessment of EPN Reproduction Rate in Different Larval Stages of S. frugiperda}

The EPN reproduction rate was assessed using the White trap method [52]. Five EPN species, namely $H$. bacteriophora, $H$. indica, S. arenarium, S. carpocapsae, and S. longicaudum, were separately added (250 IJs/larva) to $90 \mathrm{~mm}$ Petri dishes lined with filter paper containing first- to sixth-instar larvae separately $(n=5)$ and $2.5 \mathrm{~g}$ of Spodoptera artificial diet. For each EPN species, fifteen cadavers were 
individually placed on the White trap after 4 days of nematode infection and harvested nematodes were counted for 15 days using a stereo microscope (SZ-ST; Olympus, Tokyo, Japan).

\subsection{Statistical Analysis}

Statistical Analysis System version 9.4 (SAS Institute, Inc., Cary, NC, USA) was used to perform all analyses [53]. The effects of EPN species, nematode exposure time, and larval developmental stage on the mortality of $S$. frugiperda larvae were determined using three-way ANOVA. Similarly, two-way ANOVA was used to determine the effects of EPN species and larval developmental stage on nematode reproduction in S. frugiperda larvae. Abbott's formula [54] was used to calculate the corrected mortality. Lethal median time $\left(\mathrm{LT}_{50}\right)$ was calculated in SAS using the corrected mortality. Tukey's test, with significance set at $p<0.05$ [55], was used to determine the differences among treatments. All data are represented graphically as means \pm standard errors for each treatment.

\section{Results}

\subsection{Effect of EPNs on the Mortality of Different S. frugiperda Larval Stages}

Spodoptera frugiperda larval mortality at different development stages was compared among EPN treatments and treatment durations (Figure 1). Larval mortality differed significantly among the six larval stages, and it was significantly affected by EPN species and exposure time $(24,48$, and $72 \mathrm{~h}$ ) (Table 1). In first-instar larvae, S. carpocapsae and H. indica caused $100 \%$ mortality at $72 \mathrm{~h}$ post-treatment; S. longicaudum, H. bacteriophora, S. arenarium, S. kushidai, and Heterorhabditis sp. caused $60 \%, 53 \%, 50 \%, 33 \%$, and 30\% mortality, respectively. In second-instar larvae, 100\% mortality was caused by $H$. indica, S. carpocapsae, and S. longicaudum, whereas S. arenarium and H. bacteriophora caused $77 \%$ and $53 \%$ mortality, respectively, at $48 \mathrm{~h}$ post-treatment; Heterorhabditis sp. and S. kushidai did not cause any mortality. In third-instar larvae, $100 \%$ mortality was obtained with $\mathrm{H}$. indica, S. arenarium, S. carpocapsae, and S. longicaudum at $72 \mathrm{~h}$ post-treatment; H. bacteriophora caused $63 \%$ mortality, Heterorhabditis sp. caused $17 \%$ mortality, and S. kushidai caused $13 \%$ mortality under the same conditions. In fourth- and fifth-instar larvae, similar mortality patterns were observed, i.e., H. indica, S. arenarium, S. carpocapsae, and S. longicaudum produced $100 \%$ mortality at $72 \mathrm{~h}$ post-treatment. In sixth-instar larvae, $100 \%$ mortality was achieved with $H$. indica and S. carpocapsae at $72 \mathrm{~h}$ post-treatment, whereas S. arenarium, S. longicaudum, and H. bacteriophora caused $97 \%, 93 \%$, and $53 \%$ mortality, respectively. In the fourth, fifth, and sixth larval stages, Heterorhabditis sp. and S. kushidai did not cause mortality at any duration.

$\mathrm{LT}_{50}$ values for H. bacteriophora, $H$. indica, S. arenarium, S. carpocapsae, and S. longicaudum treatments against different $S$. frugiperda larval stages were calculated (Table 2). Since the mortality caused by Heterorhabditis sp. and S. kushidai was $<50 \%$ up to $72 \mathrm{~h}$ post-treatment, $\mathrm{LT}_{50}$ values for these EPNs were not calculated. Among the remaining EPNs, the $\mathrm{LT}_{50}$ values of $S$. carpocapsae were lower in the first-instar ( $\left.32 \mathrm{~h} ; \chi^{2}=37.85, \mathrm{df}=1, p=0.0001\right)$, second-instar $\left(23 \mathrm{~h} ; \chi^{2}=0.00, \mathrm{df}=1, p=0.9998\right)$, and third-instar $\left(24 \mathrm{~h} ; \chi^{2}=0.00, \mathrm{df}=1, p=0.9998\right)$ larvae. In contrast, the $\mathrm{LT}_{50}$ values of $S$. longicaudum were lower in the fourth-instar $\left(23 \mathrm{~h} ; \chi^{2}=0.00, \mathrm{df}=1, p=0.9998\right)$, fifth-instar $\left(23 \mathrm{~h} ; \chi^{2}=19.70, \mathrm{df}=1\right.$, $p=0.0001)$, and sixth-instar $\left(27 \mathrm{~h} ; \chi^{2}=0.00, \mathrm{df}=1, p=0.9998\right)$ larvae. 


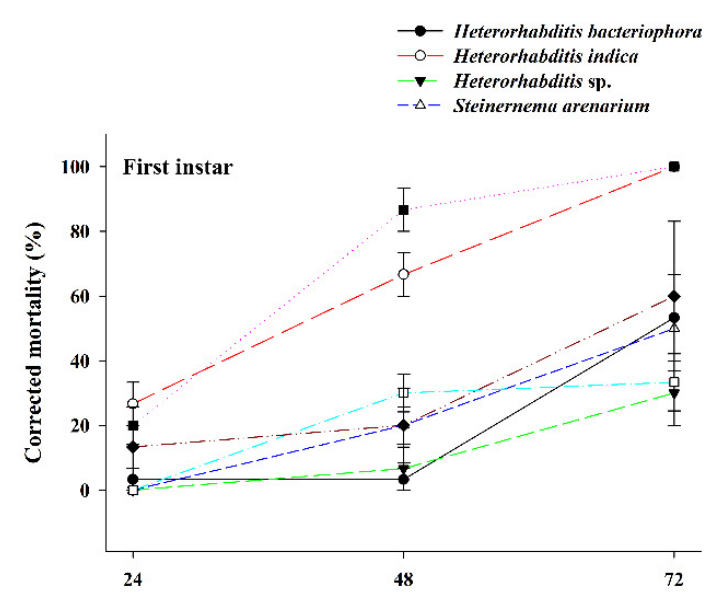

- Steinernemu carpocapsae Steinernema kushidai

- Steinernema longicaudum
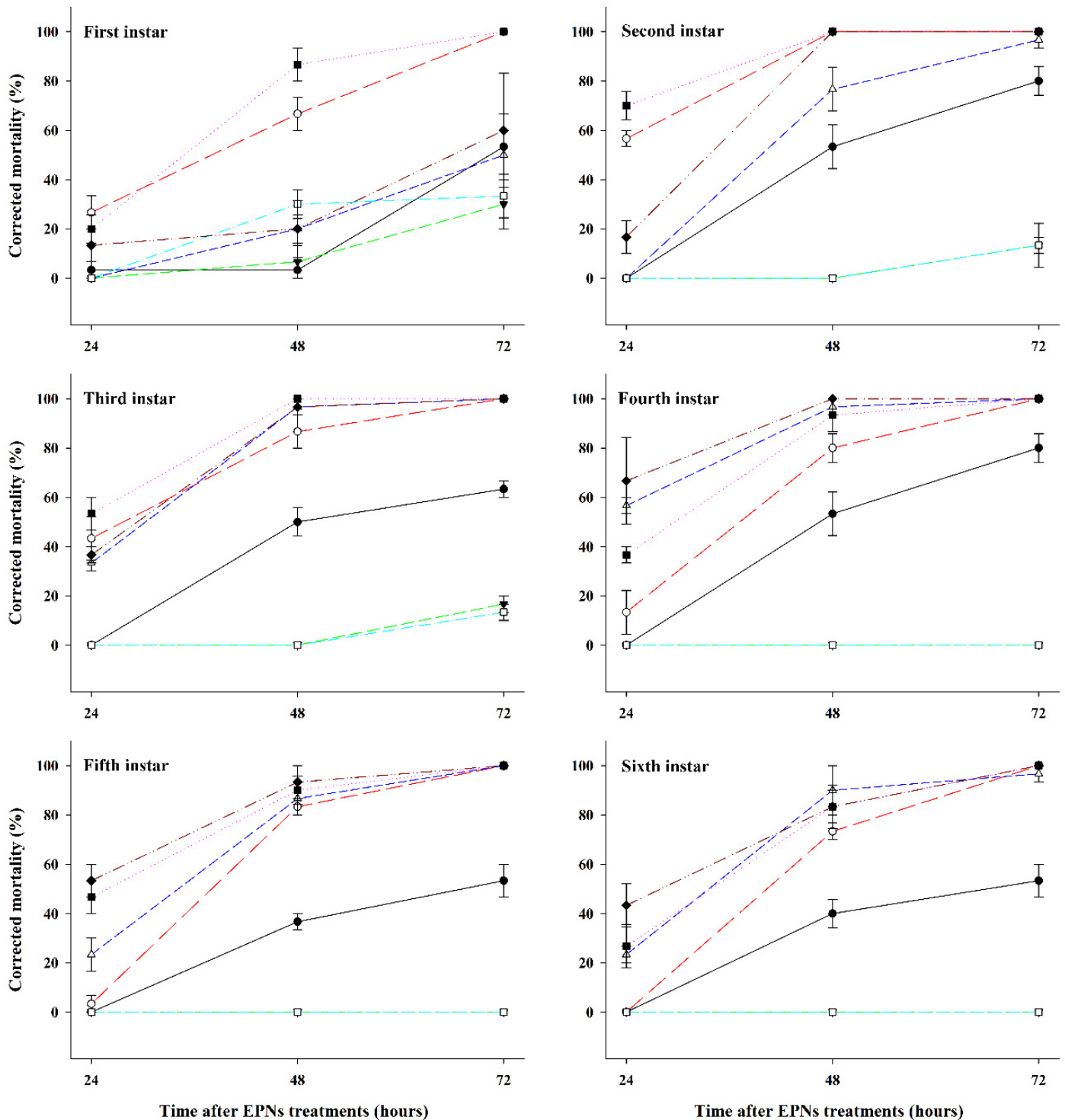

Figure 1. Corrected mortality caused by seven entomopathogenic nematodes (EPNs) in the larval stages of Spodoptera frugiperda. EPNs at a concentration of 50 infective juveniles per larva were applied to different larval stages of $S$. frugiperda and mortality rates were determined after 24,48 , and $72 \mathrm{~h}$.

Table 1. ANOVA parameters for the individual effects of larval stage, post-treatment time, entomopathogenic nematode species, and their associated interactions on the mortality of Spodoptera frugiperda larvae over $72 \mathrm{~h}$.

\begin{tabular}{cccc}
\hline Source & DF & F Value & $p$ \\
\hline Larval stage (L) & 5 & 20.29 & 0.0001 \\
Post-treatment time (T) & 2 & 579.6 & 0.0001 \\
EPN species (S) & 6 & 391.1 & 0.0001 \\
L $\times$ T & 10 & 3.3 & 0.0017 \\
L $\times$ S & 30 & 10.93 & 0.0001 \\
T $\times$ S & 12 & 29.1 & 0.0001 \\
L $\times$ T $\times$ S & 60 & 3.41 & 0.0001 \\
Error & 63 & & \\
Corrected total & 188 & & \\
\hline
\end{tabular}


Table 2. Comparison of median lethal times $\left(\mathrm{LT}_{50 \mathrm{~s}}\right)$ for entomopathogenic nematode species (EPNs) against the various developmental stages of Spodoptera frugiperda larvae.

\begin{tabular}{|c|c|c|c|c|c|}
\hline Larval Stages & EPNs & $\mathrm{LT}_{50}(\mathrm{~h})$ & $\begin{array}{c}95 \% \text { CI } \\
\text { (Lower-Upper) }\end{array}$ & Slope $( \pm$ SE $)$ & $\chi^{2}(\mathrm{df})$ \\
\hline \multirow{5}{*}{ First instar } & H. bacteriophora & $80 \mathrm{~b}$ & $(50-141)$ & 4.52 (1.13) & $15.96(1)$ \\
\hline & H. indica & $34 \mathrm{ab}$ & $(29-39)$ & $5.26(0.80)$ & $43.64(1)$ \\
\hline & S. arenarium & $84 \mathrm{bc}$ & (72-99) & $3.68(0.66)$ & 31.35 (1) \\
\hline & S. carpocapsae & $32 \mathrm{a}$ & $(28-36)$ & $6.91(1.12)$ & 37.85 (1) \\
\hline & S. longicaudum & $57 \mathrm{ab}$ & $(19-103)$ & 4.41 (1.19) & $13.74(1)$ \\
\hline \multirow{5}{*}{ Second instar } & H. bacteriophora & $51 \mathrm{e}$ & $(44-57)$ & $5.66(0.79)$ & $51.35(1)$ \\
\hline & H. indica & $24 \mathrm{~b}$ & (na) & na & $0.00(1)$ \\
\hline & S. arenarium & $42 \mathrm{~d}$ & $(36-46)$ & 9.45 (1.83) & $26.60(1)$ \\
\hline & S. carpocapsae & $23 \mathrm{a}$ & (na) & na & $0.00(1)$ \\
\hline & S. longicaudum & $26 c$ & (na) & na & $0.00(1)$ \\
\hline \multirow{5}{*}{ Third instar } & H. bacteriophora & $64 \mathrm{ab}$ & $(23-115)$ & $3.37(0.90)$ & $14.05(1)$ \\
\hline & H. indica & $27 \mathrm{ab}$ & $(21-31)$ & $5.07(0.96)$ & $28.14(1)$ \\
\hline & S. arenarium & $27 \mathrm{ab}$ & $(24-31)$ & 7.61 (1.59) & $22.85(1)$ \\
\hline & S. carpocapsae & $24 \mathrm{a}$ & (na) & na & $0.00(1)$ \\
\hline & S. longicaudum & $28 \mathrm{ab}$ & $(23-31)$ & $7.32(1.58)$ & $21.57(1)$ \\
\hline \multirow{5}{*}{ Fourth instar } & H. bacteriophora & $51 \mathrm{~d}$ & $(44-57)$ & $5.66(0.79)$ & $51.35(1)$ \\
\hline & H. indica & $35 c$ & $(31-40)$ & $7.11(1.09)$ & $42.42(1)$ \\
\hline & S. arenarium & $24 \mathrm{ab}$ & $(18-28)$ & 5.77 (1.49) & $14.95(1)$ \\
\hline & S. carpocapsae & $28 \mathrm{~b}$ & $(24-31)$ & $6.34(1.25)$ & $26.01(1)$ \\
\hline & S. longicaudum & $23 \mathrm{a}$ & (na) & na & $0.00(1)$ \\
\hline \multirow{5}{*}{ Fifth instar } & H. bacteriophora & $75 \mathrm{~d}$ & $(64-89)$ & $3.25(0.58)$ & $31.83(1)$ \\
\hline & H. indica & $27 \mathrm{~b}$ & $(24-31)$ & 7.61 (1.59) & $22.85(1)$ \\
\hline & S. arenarium & $31 \mathrm{bc}$ & $(27-36)$ & $6.58(1.09)$ & $36.54(1)$ \\
\hline & S. carpocapsae & $25 \mathrm{ab}$ & $(20-30)$ & $5.17(1.04)$ & 24.75 (1) \\
\hline & S. longicaudum & $23 \mathrm{a}$ & $(17-28)$ & $5.19(1.17)$ & $19.70(1)$ \\
\hline \multirow{5}{*}{ Sixth instar } & H. bacteriophora & $75 \mathrm{~d}$ & $(63-91)$ & $3.04(0.56)$ & $29.77(1)$ \\
\hline & H. indica & $46 \mathrm{c}$ & $(45-48)$ & $36.79(0.00)$ & $0.00(1)$ \\
\hline & S. arenarium & $31 \mathrm{ab}$ & $(27-36)$ & $5.99(0.96)$ & $39.25(1)$ \\
\hline & S. carpocapsae & $31 \mathrm{ab}$ & $(26-36)$ & $6.00(0.99)$ & 36.97 (1) \\
\hline & S. longicaudum & $27 \mathrm{a}$ & $(20-33)$ & $4.02(0.70)$ & $32.60(1)$ \\
\hline
\end{tabular}

CI: confidence interval; na: not available. Corrected mortality was used to calculate $\mathrm{LT}_{50}$ values. $\mathrm{LT}_{50}$ values followed by the same letters are not significantly different $(95 \% \mathrm{CI})$ among EPNs within the same larval stage.

\subsection{Efficacy of EPNs against S. frugiperda Larvae in the Soil Column Assay}

In the soil column assay, the mortality rates of sixth-instar $S$. frugiperda larvae were determined 48 and $72 \mathrm{~h}$ after treatment with all seven EPN species at $600 \mathrm{IJs} /$ Petri dish (Figure 2). The interaction between EPN species and post-treatment time for nematode infection was significant $(\mathrm{F}=12.73$; $\mathrm{df}=12,62 ; p<0.0001)$. Mortality was observed after $48 \mathrm{~h}$, and the rate was directly proportional to the nematode exposure time. Higher mortality occurred at $72 \mathrm{~h}$ post-treatment, with $100 \%$ mortality caused by S. carpocapsae and S. longicaudum; in contrast, H. indica, S. arenarium, H. bacteriophora, and S. kushidai achieved $93 \%, 87 \%, 57 \%$, and 10\% mortality, respectively, whereas Heterorhabditis sp. did not cause mortality over the experimental period. 


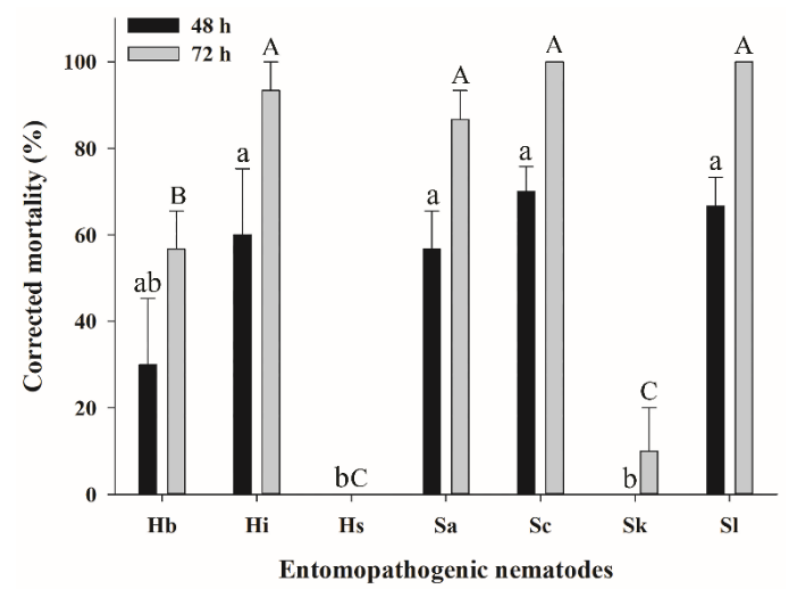

Figure 2. Corrected mortality of Spodoptera frugiperda in a soil column assay. A sixth-instar larva ( $n=1$ per glass cylinder) of $S$. frugiperda was treated with entomopathogenic nematodes (EPNs) ( $n=600$ infective juveniles) and mortality was determined 48 and $72 \mathrm{~h}$ after treatment. EPNs: Heterorhabditis bacteriophora $(\mathrm{Hb}), \mathrm{H}$. indica $(\mathrm{Hi})$, Heterorhabditis sp. (Hs), Steinernema arenarium (Sa), Steinernema carpocapsae (Sc), Steinernema kushidai (Sk), and Steinernema longicaudum (Sl). The same small and capital letters above a bar indicate that there was no significant difference in mortality between EPNs at 48 and $72 \mathrm{~h}$, respectively ( $p>0.05$, Tukey's test).

\subsection{Efficacy of EPNs against S. frugiperda Larvae in the Pot Assay}

The efficacy of five EPN species, i.e., H. bacteriophora, H. indica, S. arenarium, S. carpocapsae, and S. longicaudum, against the sixth-instar larvae of $S$. frugiperda was evaluated at $25 \mathrm{IJs} / \mathrm{cm}^{2}$ for 5 days in corn-growing pots (Figure 3 ). The mortality rates of $S$. frugiperda larvae differed significantly according to EPN species ( $\mathrm{F}=4.68 ; \mathrm{df}=4,14 ; p<0.0219)$. Among the EPNs, $S$. carpocapsae caused higher mortality $(78 \%)$ compared with the mortality caused by S. longicaudum $(71 \%)$, H. indica $(69 \%)$, and S. arenarium (62\%). Meanwhile, H. bacteriophora caused significantly lower mortality (49\%) among the tested nematodes.

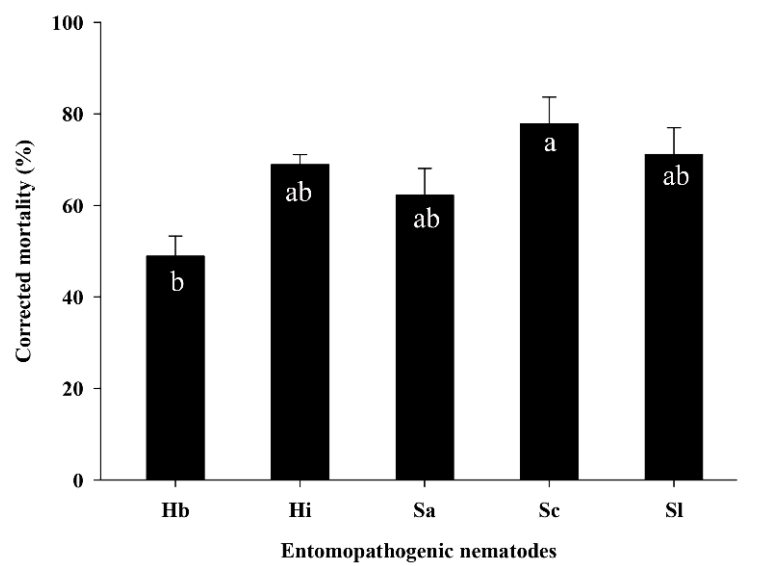

Figure 3. Corrected mortality of Spodoptera frugiperda in the corn pot assay. Sixth-instar larvae ( $n=5$ per pot) of $S$. frugiperda were treated with entomopathogenic nematodes (EPNs) $(n=25$ infective juveniles $/ \mathrm{cm}^{2}$ ) in a corn pot and mortality was determined 5 days after treatment. EPNs: Heterorhabditis bacteriophora $(\mathrm{Hb})$, Heterorhabditis indica (Hi), Steinernema arenarium (Sa), S. carpocapsae $(\mathrm{Sc})$, and S. longicaudum (Sl). The same letters in a bar indicate that there was no significant difference in mortality between EPNs ( $p>0.05$, Tukey's test). 


\subsection{Effect of EPNs on the Adult Eclosion Rate of S. frugiperda Pupae}

The effects of all seven EPN species on the adult eclosion rate of $S$. frugiperda pupae were evaluated (Figure 4). The adult eclosion rates of $S$. frugiperda pupae differed significantly among EPN species $(\mathrm{F}=9.11 ; \mathrm{df}=6,20 ; p<0.0004)$. Relative to the control, significantly lower adult eclosion rates were observed with S. carpocapsae (33\%), S. longicaudum (37\%), H. indica (40\%), S. arenarium (57\%), and $H$. bacteriophora $(60 \%)$ treatments. Eclosion rates were higher with Heterorhabditis sp. (90\%) but were not affected by S. kushidai.

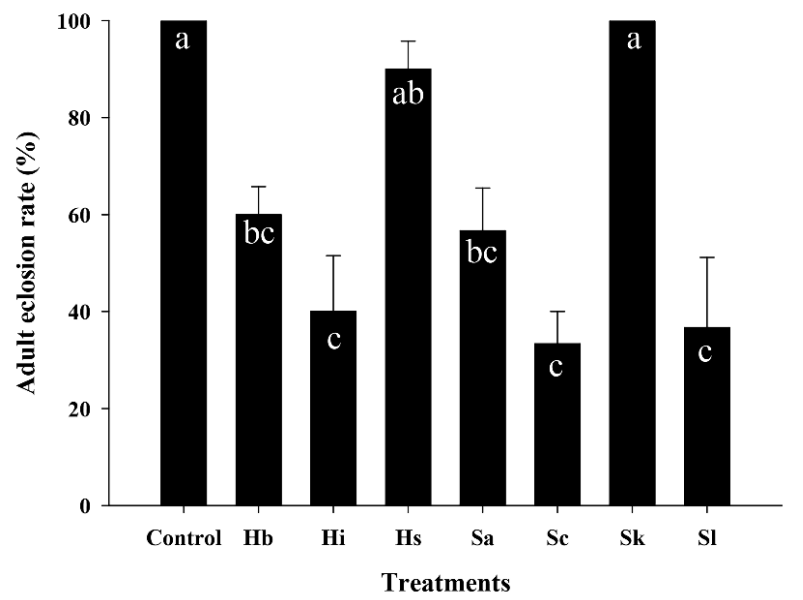

Figure 4. Effect of entomopathogenic nematodes (EPNs) on the adult eclosion rate of Spodoptera frugiperda pupae. Pupae ( $n=5$ per Petri dish) of $S$. frugiperda were treated with EPNs (600 infective juveniles) for 5 days. EPNs: Heterorhabditis bacteriophora $(\mathrm{Hb}), H$. indica (Hi), Heterorhabditis sp. (Hs), Steinernema arenarium (Sa), S. carpocapsae (Sc), S. kushidai (Sk), and S. longicaudum (Sl). The same letters in a bar indicate that there was no significant difference in the adult eclosion rate between EPNs $(p>0.05$, Tukey's test).

\subsection{EPN Reproduction Rate in Different Larval Stages of S. frugiperda}

The reproduction rates of five EPNs, i.e., H. bacteriophora, $H$. indica, S. arenarium, S. carpocapsae, and $S$. longicaudum, were compared among the various instars of $S$. frugiperda, with EPNs at a density of 50 IJs/larva (Table 3). The interaction between EPN species and S. frugiperda larval stage was significant $(\mathrm{F}=8.96 ; \mathrm{df}=20,89 ; p<0.0001)$. The EPN reproduction rate was proportional to the S. frugiperda developmental stage, with higher reproduction rates observed for $H$. indica, S. carpocapsae, and S. longicaudum in sixth-instar larvae.

Table 3. Reproduction rates (mean \pm SE) of five entomopathogenic nematodes (EPNs) in the different larval stages of Spodoptera frugiperda. In a Petri dish, each EPN was applied at a density of 50 infective juveniles per larva in each $S$. frugiperda larval stage. Nematode numbers were then counted for 15 days after treatment.

\begin{tabular}{cccccc}
\hline \multirow{2}{*}{ Larval Stages } & \multicolumn{5}{c}{ Nematode Reproduction (IJs/larva) (Mean \pm SE) } \\
\cline { 2 - 6 } & $\mathbf{H b}$ & $\mathbf{H i}$ & $\mathbf{S a}$ & Sc & S1 \\
\hline $\mathrm{L} 1$ & $639 \pm 123 \mathrm{Cb}$ & $2079 \pm 282 \mathrm{Ca}$ & $858 \pm 148 \mathrm{C} \mathrm{ab}$ & $1836 \pm 456 \mathrm{Dab}$ & $981 \pm 182 \mathrm{Dab}$ \\
$\mathrm{L} 2$ & $2213 \pm 225 \mathrm{Cb}$ & $4356 \pm 527 \mathrm{Ca}$ & $3308 \pm 312 \mathrm{Cab}$ & $4523 \pm 290 \mathrm{DEa}$ & $3431 \pm 244 \mathrm{DEab}$ \\
$\mathrm{L} 3$ & $4447 \pm 401 \mathrm{Cb}$ & $7411 \pm 819 \mathrm{Ca}$ & $5957 \pm 480 \mathrm{Cab}$ & $7980 \pm 854 \mathrm{Da}$ & $6597 \pm 912 \mathrm{Dab}$ \\
$\mathrm{L} 4$ & $14,083 \pm 1433 \mathrm{BCab}$ & $30,963 \pm 3961 \mathrm{Ba}$ & $24,987 \pm 2031 \mathrm{Ba}$ & $26,200 \pm 1010 \mathrm{Ca}$ & $25,706 \pm 1244 \mathrm{Ca}$ \\
$\mathrm{L} 5$ & $18,443 \pm 1499 \mathrm{Bab}$ & $47,930 \pm 2323 \mathrm{Aa}$ & $24,988 \pm 2031 \mathrm{ABa}$ & $36,537 \pm 3002 \mathrm{Bbc}$ & $39,822 \pm 1504 \mathrm{Bab}$ \\
$\mathrm{L} 6$ & $30,308 \pm 1789 \mathrm{Aab}$ & $58,753 \pm 4047 \mathrm{Aa}$ & $35,867 \pm 1975 \mathrm{Ab}$ & $58,433 \pm 3349 \mathrm{Aa}$ & $57,990 \pm 2837 \mathrm{Aa}$ \\
\hline
\end{tabular}

EPNs: Heterorhabditis bacteriophora $(\mathrm{Hb}), H$. indica $(\mathrm{Hi})$, Steinernema arenarium $(\mathrm{Sa})$, S. carpocapsae $(\mathrm{Sc})$, and S. longicaudum (S1). L1-L6 represent the larval stages of $S$. frugiperda. The same uppercase letter in the same column indicates that there was no significant difference in reproduction rate between the larval stages; the same lowercase letter in the same row indicates that there was no significant difference in reproduction rate between the EPN species $(p>0.05$, Tukey's test). 


\section{Discussion}

The virulence of EPNs depends on their innate characteristics as well as the conditions of their hosts $[42,47,48,56]$. Our results revealed that EPN virulence differed significantly among EPN species, exposure durations, and the developmental stages of S. frugiperda. Among the seven tested EPNs, H. bacteriophora, H. indica, S. arenarium, S. carpocapsae, and S. longicaudum were virulent to varying extents in all S. frugiperda larval stages, whereas Heterorhabditis sp. and S. kushidai caused mortality only in early instars. EPN virulence was dependent on the developmental stage of the host $S$. frugiperda: both $H$. indica and S. carpocapsae were highly virulent in younger instars (e.g., first-, second-, and third-instar larvae), whereas both S. arenarium and S. longicaudum were highly virulent in older instars (e.g., fourth-, fifth-, and sixth-instar larvae). The body lengths of H. indica and S. carpocapsae were 500 and $581 \mu \mathrm{m}$, respectively, whereas those of $S$. arenarium and S. longicaudum were 1082 and $832 \mu \mathrm{m}$, respectively; thus, the body size of an EPN species seems to be associated with virulence at different developmental stages of the host insect. Our results are consistent with previous studies. For example, Park et al. [34] reported that larger nematodes were able to penetrate larger host insects. In addition, Yan et al. [42] reported that $S$. arenarium was more virulent against third- and fourth-instar larvae of $S$. litura than against second-instar larvae. However, Patil et al. [56] reported that the virulence of $S$. carpocapsae did not differ between the second and fourth instars of Mythimna separata larvae.

The reproduction rate of EPNs is also influenced by the different developmental stages of host insects [34]. Our results indicate that the reproduction rates of five EPNs were significantly dependent on the larval stage of S. frugiperda. Specifically, the reproduction rates of $H$. indica, S. carpocapsae, and S. longicaudum were higher in sixth-instar larvae than in younger developmental stages. This result is consistent with a previous study that showed the reproduction rates of $H$. indica and S. longicaudum were higher in the fifth and sixth instars of S. litura [28].

Many studies report that lepidopteran pupae are also susceptible to EPNs [39,42,56-59]. For example, Kaya and Hara [57] reported that lepidopteran pupae are susceptible to Steinernema feltiae, which caused at least 47\% mortality with 200 IJs. Similarly, Fuxa et al. [39] reported that S. feltiae successfully killed 7-20\% of S. frugiperda pupae. The present study showed that three EPN species, namely $H$. indica, S. carpocapsae, and S. longicaudum, were highly lethal to S. frugiperda pupae, whereas S. kushidai was not effective. Yan et al. [42] also reported that S. carpocapsae and H. indica were highly virulent against $S$. litura pupae.

Previous studies have reported that $S$. carpocapsae is highly effective as a biological control against lepidopteran pests $[28,36,60]$. The present study also indicated that $S$. frugiperda larvae were most susceptible to $S$. carpocapsae, although other EPNs, such as H. indica, S. arenarium, and S. longicaudum, were also effective in the soil column and pot assays. Campbell et al. [61] reported that $S$. carpocapsae remains in the upper layer of soil to a large extent, whereas H. bacteriophora is uniformly distributed to a depth of up to $8 \mathrm{~cm}$ in the soil. Moyle and Kaya [62] and Pathak et al. [63] reported in their respective studies that more than $90 \%$ of applied S. carpocapsae and S. frugiperda larvae remain in the soil (2.5-5 cm depth). To validate the present results, the control efficacy of $S$. carpocapsae, as well as other EPNs, against $S$. frugiperda should be evaluated in a field study. Soil factors such as texture, moisture, $\mathrm{pH}$, and depth also affect the control efficacy of EPNs. In general, higher efficacy of EPNs was observed in sandy soil than clay soil [64]; however, other studies reported that EPN efficacy was higher in clay soil than sandy soil $[65,66]$. Further investigation is required to understand the effects of soil parameters on EPN efficacy.

\section{Conclusions}

In conclusion, S. frugiperda was highly susceptible at larval and pupal stages to various EPNs including S. carpocapsae, H. indica, and S. longicaudum. These EPNs, therefore, could potentially be used as biological control agents to sustainably manage the overlapping generations of S. frugiperda in the environment. 
Author Contributions: Conceptualization, R.A. and K.-Y.L.; methodology, R.A., H.-S.H., M.M.M. and K.-Y.L.; formal analysis, R.A.; resources, R.A., H.-S.H., M.M.M., Y.-S.Y. and K.-Y.L.; writing一original draft preparation, R.A.; writing - review and editing, Y.-S.Y. and K.-Y.L.; funding acquisition, Y.-S.Y. and K.-Y.L. All authors have read and agreed to the published version of the manuscript.

Funding: This study was supported by a research grant (\#117044-3) from the Ministry of Agriculture, Food, and Rural Affairs of the Republic of Korea.

Acknowledgments: We are very grateful to Young-Jun Kim for the collection of the entomopathogenic nematodes.

Conflicts of Interest: The authors declare that they have no conflict of interest.

\section{References}

1. Goergen, G.; Kumar, P.L.; Sankung, S.B.; Togola, A.; Tamò, M. First report of outbreaks of the fall armyworm Spodoptera frugiperda (J E Smith) (Lepidoptera, Noctuidae), a new alien invasive pest in West and Central Africa. PLoS ONE 2016, 11, e0165632. [CrossRef] [PubMed]

2. Jing, D.P.; Guo, J.F.; Jiang, Y.Y.; Zhao, J.Z.; Sethi, A.; He, K.L.; Wang, Z.Y. Initial detections and spread of invasive Spodoptera frugiperda in China and comparisons with other noctuid larvae in cornfields using molecular techniques. Insect Sci. 2020, 27, 780-790. [CrossRef] [PubMed]

3. Lee, G.; Seo, B.Y.; Lee, J.; Kim, H.; Song, J.H.; Lee, W. First report of the fall armyworm, Spodoptera frugiperda (Smith, 1797) (Lepidoptera, Noctuidae), a new migratory pest in Korea. Korean J. Appl. Entomol. 2020, 59, 73-78. [CrossRef]

4. EPPO Spodoptera frugiperda (LAPHER). Available online: https://gd.eppo.int/taxon/LAPHFR/distribution (accessed on 12 October 2020).

5. Clark, P.L.; Molina-Ochoa, J.; Martinelli, S.; Skoda, S.R.; Isenhour, D.J.; Lee, D.J.; Krumm, J.T.; Foster, J.E. Population variation of the fall armyworm, Spodoptera frugiperda, in the Western Hemisphere. J. Insect Sci. 2007, 7, 1-10. [CrossRef] [PubMed]

6. Nagoshi, R.N. Can the amount of corn acreage predict fall armyworm (Lepidoptera: Noctuidae) infestation levels in nearby cotton? J. Econ. Entomol. 2009, 102, 210-218. [CrossRef] [PubMed]

7. Day, R.; Abrahams, P.; Bateman, M.; Beale, T.; Clottey, V.; Cock, M.; Colmenarez, Y.; Corniani, N.; Early, R.; Godwin, J.; et al. Fall armyworm: Impacts and implications for Africa. Outlooks on pest management. Outlooks Pest Manag. 2017, 28, 196-201. [CrossRef]

8. Sisay, B.; Simiyu, J.; Mendesil, E.; Likhayo, P.; Ayalew, G.; Mohamed, S.; Subramanian, S.; Tefera, T. Fall armyworm, Spodoptera frugiperda infestations in East Africa: Assessment of damage and parasitism. Insects 2019, 10, 195. [CrossRef]

9. Carvalho, R.A.; Omoto, C.; Field, L.M.; Williamson, M.S.; Bass, C. Investigating the molecular mechanisms of organophosphate and pyrethroid resistance in the fall armyworm Spodoptera frugiperda. PLoS ONE 2013, 8, e62268. [CrossRef]

10. Diez-Rodríguez, G.I.; Omoto, C. Inheritance of lambda-cyhalothrin resistance in Spodoptera frugiperda (J.E. Smith) (Lepidoptera: Noctuidae). Neotrop. Entomol. 2001, 30, 311-316. [CrossRef]

11. do Nascimento, A.R.B.; Farias, J.R.; Bernardi, D.; Horikoshi, R.J.; Omoto, C. Genetic basis of Spodoptera frugiperda (Lepidoptera: Noctuidae) resistance to the chitin synthesis inhibitor lufenuron. Pest Manag. Sci. 2016, 72, 810-815. [CrossRef]

12. Blanco, C.A.; Portilla, M.; Jurat-Fuentes, J.L.; Sánchez, J.F.; Viteri, D.; Vega-Aquino, P.; Terán-Vargas, A.P.; Azuara-Domínguez, A.; López, J.D.; Arias, R.; et al. Susceptibility of isofamilies of Spodoptera frugiperda (Lepidoptera: Noctuidae) to Cry1Ac and Cry1Fa proteins of Bacillus thuringiensis. Southwest. Entomol. 2010, 35, 409-415. [CrossRef]

13. Huang, F.; Qureshi, J.A.; Meagher, R.L.; Reisig, D.D.; Head, G.P.; Andow, D.A.; Ni, X.; Kerns, D.; Buntin, G.D.; Niu, Y.; et al. Cry1F resistance in fall armyworm Spodoptera frugiperda: Single gene versus pyramided Bt maize. PLoS ONE 2014, 9, e112958. [CrossRef] [PubMed]

14. Malhat, F.M.; Haggag, M.N.; Loutfy, N.M.; Osman, M.A.M.; Ahmed, M.T. Residues of organochlorine and synthetic pyrethroid pesticides in honey, an indicator of ambient environment, a pilot study. Chemosphere 2015, 120, 457-461. [CrossRef] [PubMed]

15. Mostafalou, S.; Abdollahi, M. Pesticides and human chronic diseases: Evidences, mechanisms, and perspectives. Toxicol. Appl. Pharmacol. 2013, 268, 157-177. [CrossRef] [PubMed] 
16. Prasanna, B.; Huesing, J.E.; Eddy, R.; Peschke, V.M. Fall Armyworm in Africa: A guide for integrated pest management. In Handbook, 1st ed.; CDMX CIMMYT: Texcoco, Mexico, 2018; pp. 45-62.

17. Akutse, K.S.; Kimemia, J.W.; Ekesi, S.; Khamis, F.M.; Ombura, O.L.; Subramanian, S. Ovicidal effects of entomopathogenic fungal isolates on the invasive fall armyworm Spodoptera frugiperda (Lepidoptera: Noctuidae). J. Appl. Entomol. 2019, 143, 626-634. [CrossRef]

18. Brixey, J. The potential for biological control to reduce Hylobius abietis damage. For. Comm. Res. Inf. Note 1997, 273, 1-6.

19. Andalo, V.; Santos, V.; Moreira, G.F.; Moreira, C.C.; Junior, A.M. Evaluation of entomopathogenic nematodes under laboratory and greenhouses conditions for the control of Spodoptera frugiperda. Cienc. Rural 2010, 40, 1860-1866. [CrossRef]

20. Giannasi, A.D.O.; Brambila, C.R.; Zart, M.; Guide, B.A.; Alves, V.S. Assessment of entomopathogenic nematodes in Agrotis ipsilon (Lepidoptera: Noctuidae) under laboratory and greenhouse conditions. Rev. Colomb. Entomol. 2018, 44, 25-31. [CrossRef]

21. Viteri, D.M.; Linares, A.M.; Flores, L. Use of the entomopathogenic nematode Steinernema carpocapsae in combination with low-toxicity insecticides to control fall armyworm (Lepidoptera: Noctuidae) Larvae. Florida Entomol. 2018, 101, 327-329. [CrossRef]

22. Bhat, A.H.; Chaubey, A.K.; Askary, T.H. Global distribution of entomopathogenic nematodes, Steinernema and Heterorhabditis. Egypt. J. Biol. Pest Control 2020, 30. [CrossRef]

23. Hominick, W.M. Biogeography. In Entomopathogenic Nematology; Gaugler, R., Ed.; CABI Publishing: Wallingford, UK, 2002; pp. 115-144.

24. Laznik, Ž.; Tóth, T.; Lakatos, T.; Vidrih, M.; Trdan, S. Control of the Colorado potato beetle (Leptinotarsa decemlineata [Say]) on potato under field conditions: A comparison of the efficacy of foliar application of two strains of Steinernema feltiae (Filipjev) and spraying with thiametoxam. J. Plant Dis. Prot. 2010, 117, 129-135. [CrossRef]

25. Kepenekci, I.; Hazir, S.; Özdem, A. Evaluation of native entomopathogenic nematodes for the control of the European cherry fruit fly Rhagoletis cerasi L. (Diptera: Tephritidae) larvae in soil. Turkish J. Agric. For. 2015, 39, 74-79. [CrossRef]

26. Oreste, M.; Baser, N.; Ibouh, K.; Verrastro, V.; Tarasco, E. Potential of entomopathogenic fungi and nematodes against Drosophila suzukiiin laboratory assays. Microb. Nematode Control Invertebr. Pests IOBC-WPRS Bull. 2017, 129, 77-78.

27. Yuksel, E.; Taskesen, Y.E.; Erarslan, D.; Canhilal, R. Effectiveness of different entomopathogenic nematode species against the variegated cutworm, Peridroma saucia (Hubner) (Lepidoptera: Noctuidae). Egypt. J. Biol. Pest Control 2018, 28, 2-5. [CrossRef]

28. Acharya, R.; Yu, Y.-S.; Shim, J.-K.; Lee, K.-Y. Virulence of four entomopathogenic nematodes against the tobacco cutworm Spodoptera litura Fabricius. Biol. Control 2020, 150, 104348. [CrossRef]

29. Kaya, H.K.; Gaugler, R. Entomopathogenic nematodes. Annu. Rev. Entomol. 1993, 181-206. [CrossRef]

30. Gaugler, R. Entomopathogenic Nematology; CABI: New York, NY, USA, 2002.

31. Dowds, B.C.; Peters, A. Virulence mechanism. In Entomopathogenic Nematology; Gaugler, R., Ed.; CABI International: Wallingford, UK, 2002; pp. 79-98.

32. Griffin, C.T.; Boemare, N.E.; Lewis, E.E. Biology and behaviour. In Nematodes as Biocontrol Agents; Grewal, P.S., Ehlers, R.U., Shapiro-Ilan, D.I., Eds.; CABI Publishing: Wallingford, UK, 2005; pp. 47-64.

33. Kaya, H.K.; Aguillera, M.M.; Alumai, A.; Choo, H.Y.; de la Torre, M.; Fodor, A.; Ganguly, S.; Hazir, S.; Lakatos, T.; Pye, A.; et al. Status of entomopathogenic nematodes and their symbiotic bacteria from selected countries or regions of the world. Biol. Control 2006, 38, 134-155. [CrossRef]

34. Park, S.H.; Yu, Y.S.; Park, J.S.; Choo, H.Y.; Do Bae, S.; Nam, M.H. Biological control of tobacco cutworm, Spodoptera litura fabricius with entomopathogenic nematodes. Biotechnol. Bioprocess Eng. 2001, 6, 139-143. [CrossRef]

35. Stock, S.P.; Kusakabe, A.; Orozco, R.A. Secondary metabolites produced by Heterorhabditis symbionts and their application in agriculture: What we know and what to do next. J. Nematol. 2017, 49, 373-383. [CrossRef]

36. Caroli, L.; Glazer, I.; Gaugler, R. Entomopathogenic nematode infectivity assay: Comparison of penetration rate into different hosts. Biocontrol Sci. Technol. 1996, 6, 227-234. [CrossRef]

37. Simões, N.; Rosa, J.S. Pathogenicity and host specificity of entomopathogenic nematodes. Biocontrol Sci. Technol. 1996, 6, 403-412. [CrossRef] 
38. Ramos-Rodríguez, O.; Campbell, J.F.; Ramaswamy, S.B. Pathogenicity of three species of entomopathogenic nematodes to some major stored-product insect pests. J. Stored Prod. Res. 2006, 42, 241-252. [CrossRef]

39. Fuxa, J.R.; Richter, A.R.; Acudelo-Silva, F. Effect of host age and nematode strain on susceptibility of Spodoptera frugiperda to Steinernema feltiae. J. Nematol. 1988, 20, 91-95. [PubMed]

40. Jackson, J.J.; Brooks, M.A. Parasitism of western corn rootworm larvae and pupae by Steinernema carpocapsae. J. Nematol. 1995, 27, 15-20. [PubMed]

41. Acharya, R.; Hwang, H.-S.; Shim, J.-K.; Yu, Y.-S.; Lee, K.-Y. Control efficacy of fungus gnat, Bradysia impatiens, enhanced by a combination of entomopathogenic nematodes and predatory mites. Biol. Control 2019, 138, 104071. [CrossRef]

42. Yan, X.; Shahid Arain, M.; Lin, Y.; Gu, X.; Zhang, L.; Li, J.; Han, R. Efficacy of entomopathogenic nematodes against the tobacco cutworm, Spodoptera litura (Lepidoptera: Noctuidae). J. Econ. Entomol. 2020, 113, 64-72. [CrossRef] [PubMed]

43. Garcia, L.C.; Raetano, C.G.; Leite, L.G. Application technology for the entomopathogenic nematodes Heterorhabditis indica and Steinernema sp. (Rhabditida: Heterorhabditidae and Steinernematidae) to control Spodoptera frugiperda (Smith) (Lepidoptera: Noctuidae) in corn. Neotrop. Entomol. 2008, 37, 305-311. [CrossRef]

44. Caccia, M.G.; Del Valle, E.; Doucet, M.E.; Lax, P. Susceptibility of Spodoptera frugiperda and Helicoverpa gelotopoeon (Lepidoptera: Noctuidae) to the entomopathogenic nematode Steinernema diaprepesi (Rhabditida: Steinernematidae) under laboratory conditions. Chil. J. Agric. Res. 2014, 74, 123-126. [CrossRef]

45. Platt, T.; Stokwe, N.F.; Malan, A.P. A review of the potential use of entomopathogenic nematodes to control above-ground insect pests in South Africa. S. Afr. J. Enol. Vitic. 2020, 41, 1-16. [CrossRef]

46. Guo, W.; Yan, X.; Zhao, G.; Han, R. Efficacy of entomopathogenic Steinernema and Heterorhabditis nematodes against white grubs (Coleoptera: Scarabaeidae) in peanut fields. J. Econ. Entomol. 2013, 106, 1112-1117. [CrossRef]

47. Kapranas, A.; Sbaiti, I.; Degen, T.; Turlings, T.C.J. Biological control of cabbage fly Delia radicum with entomopathogenic nematodes: Selecting the most effective nematode species and testing a novel application method. Biol. Control 2020, 144, 104212. [CrossRef]

48. Ö̈̆retmen, A.; Yüksel, E.; Canhilal, R. Susceptibility of larvae of wireworms (Agriotes spp.) (Coleoptera: Elateridae) to some Turkish isolates of entomopathogenic nematodes under laboratory and field conditions. Biol. Control 2020, 149. [CrossRef]

49. Mamiya, Y. Comparison of the infectivity of Steinernema kushidai and other nematodes for three different insects. Appl. Entomol. Zool. 1989, 24, 302-308. [CrossRef]

50. Ogura, N. Control of scarabaeid grubs with an entomogenous nematode, Steinernema kushidai. Japan Agric. Res. Q. 1993, 27, 49-54.

51. Woodring, J.L.; Kaya, H.K. Steinernematid and heterorhabditid nematodes: A handbook of biology and techniques. South Coop. Ser. Bull. 1988, 331.

52. White, G.F. A method for obtaining infective nematodes larvae from cultures. Science 1927, 66, 302. [CrossRef] [PubMed]

53. SAS Institute Inc. Base SAS 9.4 Procedures Guide, Statistical Procedures, 2nd ed.; SAS Institute Inc.: Cary, NC, USA, 2013.

54. Abbott, W.S. The valueof the dry substitutes for liquid lime. J. Econ. Entomol. 1925, 18, 265-267. [CrossRef]

55. Littell, R.C.; Stroup, W.W.; Freund, R.J. SAS for Linear Models; SAS Publishing: Cary, NC, USA, 2002.

56. Patil, J.; Vijayakumar, R.; Linga, V.; Sivakumar, G. Susceptibility of Oriental armyworm, Mythimna separata (Lepidoptera: Noctuidae) larvae and pupae to native entomopathogenic nematodes. J. Appl. Entomol. 2020, 1-8. [CrossRef]

57. Kaya, H.K.; Hara, A.H. Susceptibility of various species of lepidopterous pupae to the entomogenous nematode. Neoaplectana carpocapsae. J. Nematol. 1981, 13, 291-294.

58. Kondo, E.; Ishibashi, N. Infection efficacyof Steinernema feltiae (DD-136) to thecommon cutworm, Spodoptera litura (Lepidoptera: Noctuidae), on the soil. Appl. Entomol. Zool. 1986, 21, 561-571. [CrossRef]

59. Narayanan, K.; Gopalakrishnan, C. Effect of entomogenous nemamode, Steinernema feltiae (Rhabditida: Steinernematldae) to the pre-pupa, pupa and adult of Spodoptera litura (Noctuidae: Lepidoptera). Indian J. Nematol. $1987,17,273-276$. 
60. Gulcu, B.; Ulug, D.; Hazir, C.; Karagoz, M.; Hazir, S. Biological control potential of native entomopathogenic nematodes (Steinernematidae and Heterorhabditidae) against Spodoptera cilium (Lepidoptera: Noctuidae) in turfgrass. Biocontrol Sci. Technol. 2014, 24, 965-970. [CrossRef]

61. Campbell, J.F.; Lewis, E.; Yoder, F.; Gaugler, R. Entomopathogenic nematode (Heterorhabditidae and Steinernematidae) spatial distribution in turfgrass. Parasitology 1996, 113, 473-482. [CrossRef] [PubMed]

62. Moyle, P.L.; Kaya, H.K. Dispersal and infectivityof the entomogenous nematode, Neoaplectana carpocapsae Weiser (Rhabditida: Steinernematidae), in sand. J. Nematol. 1981, 13, 295-300.

63. Pathak, M.D.; Khan, J.R. Insect Pests of Rice; International Rice Research Institute (IRRI): Los banios, Philippines; International Centre of Insect Physiology and Ecology (ICIPE): Nairobi, Kenya, 1994; p. 89.

64. El-Borai, F.E.; Stuart, R.J.; Campos-Herrera, R.; Pathak, E.; Duncan, L.W. Entomopathogenic nematodes, root weevil larvae, and dynamic interactions among soil texture, plant growth, herbivory, and predation. J. Invertebr. Pathol. 2012, 109, 134-142. [CrossRef]

65. Toledo, J.; Williams, T.; Pérez, C.; Liedo, P.; Valle, J.F.; Ibarra, J.E. Abiotic factors affecting the infectivity of Steinernema carpocapsae (Rhabditida: Steinernematidae) on larvae of Anastrepha obliqua (Diptera: Tephritidae). Biocontrol Sci. Technol. 2009, 19, 887-898. [CrossRef]

66. Toepfer, S.; Kurtz, B.; Kuhlmann, U. Influence of soil on the efficacy of entomopathogenic nematodes in reducing Diabrotica virgifera virgifera in maize. J. Pest Sci. 2010, 83, 257-264. [CrossRef]

Publisher's Note: MDPI stays neutral with regard to jurisdictional claims in published maps and institutional affiliations. 